\title{
Rapid Detection of Streptococci in Cultured Tilapia Fish Using PCR and Chemical Analysis
}

\author{
Gehan I E Ali ${ }^{1}$, Hala A M Abd El-Hady ${ }^{2}$, and Mayada A M Abou Zeid ${ }^{2 *}$ \\ ${ }^{I}$ Biochemistry, Kafr El sheikh Regional Laboratory, Animal Health Research Institute, Agricultural Research Center(ARC), Egypt. \\ ${ }^{2}$ Bacteriology, Kafr El sheikh Regional Laboratory, Animal Health Research Institute, Agricultural Research Center(ARC), Egypt. \\ *Corresponding author's Email: kindmemo@yahoo.com; iDORCiD: 0000-0002-5733-8606
}

\begin{abstract}
Streptococcosis causes economic losses due to the high mortality in Nile tilapia (Oreochromis niloticus). The present study was carried out to detect the streptococci by PCR and chemical analysis in cultured tilapia fish. A total of 100 cultured tilapia fishes and 20 water samples were collected from 4 different fish farms at different locations in Kafr El-sheikh Governorate for bacteriological and chemical analysis. The results of water quality parameters examination revealed that the mean values of $\mathrm{pH}$, dissolved oxygen, unionized ammonia, and nitrite were $8.2 \pm 0.73$, $7.44 \pm 0.54$ parts per million $(\mathrm{ppm}), 0.05 \pm 0.008 \mathrm{ppm}$, and $0.00 \mathrm{ppm}$, respectively. All water quality parameters except for ammonia were within the permissible limit. The bacterial isolation results revealed $38 \%$ positive samples for Streptococcus species isolated from tilapia fishes and $40 \%$ were positive for Streptococcus species isolated from water samples. Of those 38 positive fish samples, 25 (65.78\%) were Enterococcus faecalis, $15(39.47 \%)$ were Streptococcus pyogenes, 6 (15.78\%) were Enterococcus faecium, 5 (13.15\%) were Streptococcus agalactiae, and 3 (7.89\%) were Streptococcus iniae. On the other hand, from 8 positive farms water samples, $7(87.5 \%)$ were Enterococcus faecalis, 2 (25\%) were Streptococcus pyogenes , 2 (25\%) were Enterococcus faecium, 3 (37.5\%) were Streptococcus agalactiae, and $1(12.5 \%)$ was Streptococcus iniae. Using mPCR to identify Streptococcus for some fish and water isolates, 6 Enterococcus faecalis with 310 base per (bp) were detected while 3 Streptococcus agalactiae with 153 bp and 2 Enterococcus faecium at 215 bp were detected. However, the mPCR from Streptococcus species directly from organs from fish and water samples revealed that 5 Enterococcus faecalis were detected at $310 \mathrm{bp}$ while 2 Streptococcus agalactiae was identified at $153 \mathrm{bp}$. The biochemical results indicated that the infected fish with the streptococcal species had reduced total protein, albumin, and globulin in the blood serum while total cholesterol, urea, creatinine levels, and AST, ALT, GPX, CAT, SOD activities significantly increased, compared to non- infected fish.
\end{abstract}

Keywords: Biochemical parameters, PCR, Streptococci, Tilapia fish, Water examination.

\section{INTRODUCTION}

The second most common fish species in tropical and subtropical freshwater aquaculture is Oreochromis niloticus (FAO, 2018). Tilapia is a common aquacultured fish and an important seafood source for human consumption. Up to date, little known is about their usual physiology and reaction to disease infections. Subsequently, ceaseless development of tilapia wellbeing evaluation strategies is fundamental. In any event, the hematology methods commonly utilized for demonstrative clinical infections in the veterinary world are still restricted in aquatic animal pharmaceuticals (Chen et al., 2003).

Bacterial infections in cultivated tilapia were considered the foremost critical causes for financial misfortunes. Vibrio anguillarum, Aeromonas species, Flavobacterium columnare, Pseudomonas fluorescens, Streptococcus species, Edwardsiella tarda, and Enterococcus species Were found commonly in aquaculture establishment (Plumb, 1997). Various studies help detect fish bacteria, laboratory infection or resistance to disease (Azad et al., 2001; Al-Harbi and Uddin, 2004; Cai, et al, 2004) still few links haematological parameters with experimental bacterial infection. Hematological parameters are important diagnostic tools that indicate the health state of fish (Blaxhall, 1972; Rehulka, 2002; Martins et al., 2004).

Streptococcus species, for the most part, are astute aquaculture pathogens, the pathogenicity of which is influenced by environmental stresses such as low oxygen levels and a high nitrite concentration (Bunch and Bejerano, 1997), water hardness, overfilling with removed scales (Wedmeyer, 1997) and water temperatures over $20{ }^{\circ} \mathrm{C}$ (Ohnishi and Jo, 1981). All vital organs of the infected fish with streptococci are heavily infected and the mortality is enormous (50-60\%) (Hubbert, 1989).

Streptococcosis is a bacterial disease in fish that causes economic losses in the freshwater and marine fish production, which is economically important in many countries, including the tilapia industry. Streptococcus species that cause disease in fish include $S$. agalactiae, $S$. dysgalactiae, and $S$. equi, S. equisimilis, S. faecium, S. pyogenes, $S$. zooepidemicus, and S.iniae. Previous case reports showed that S. agalactiae and S. iniae are the main causative agents of 
streptococcosis in Tilapia. Moreover, the World Animal Health Organization (OIE) has declared that S.iniae is a zoonosis (Amal, 2011). The acute form of streptococcal infection in O. niloticus has resulted in more than $50 \%$ mortalities for about 3 days to one week, while the chronic form could last for several weeks, with the low rate daily mortality being approximately one or two percent (Osman et al., 2017).

The aim of the present project was to isolate streptococcus species from tilapia fish and water samples by the traditional method by isolation and identification, then by using multiplex PCR for conformation of some streptococcus isolates and a rapid method to detect streptococcus species directly from organs of fish and water samples. Also, this experiment was conducted to diagnose streptococcal infection using water quality parameters estimation and biochemical parameters, since diagnostic techniques to detect pathogenic bacteria responsible for fish streptococcosis are usually based on the cultured technique, which requires several days to reach a definitive diagnosis leading to increased disease outbreak risk.

\section{MATERIALS AND METHODS}

\section{Ethical approval}

The experimental design was performed in accordance with the Guidelines for Animal Experimentation of the Ethics Review Committee of the Animal Health Research Institute, Giza, Egypt (Approval No 83429).

\section{Samples collection}

A total of 100 Nile tilapia fishes were collected from live or freshly dead fishes with at least one or more clinical signs of eye lesions and opacity, septicemia, skin lesions, detached scales, skin congestion, ulcers, hemorrhage, and congestion of fins. Twenty water samples were collected from four different fish farms at different locations in Kafr El sheikh Governorate and transported to the Animal Health Research Institute Kafr El sheikh branch, Egypt. The fishes were transported in a sterile polythene bag, which was supplied with aerated tap water with chlorine-free water from fish farms and subjected to biochemical and bacteriological examinations.

\section{Water quality sampling and measurement}

Water quality at a depth of 1 meter in each farm was measured at five clear sampling points. A similar technique was used to sample the fish. The water quality parameters for $\mathrm{pH}$ and dissolved oxygen were measured using a handheld meter (ORION 5 STAR). The concentration of water nitrite and unionized ammonia was measured using powder pillow procedures and using a spectrophotometer to measure the concentration (HACH Company, Loveland, CO, USA). According to (APHA, 1998)

\section{Bacteriological examinations \\ Bacterial isolation}

Tissue samples from the brain, kidney, liver, spleen, and eyes of the fish were homogenized in a sample, which was used for the fish sampling according to Aboyadak et al. (2016) representative. Tissue samples were divided into two parts, one processed directly for multiplex PCR by sending it to the Dokki Laboratory, and the other was primarily cultivated on Tryptic Soy Broth (TSB) from each sample at $37^{\circ} \mathrm{C}$ for 48 hours. A loopful from each tryptic soy broth tube was streaked on Edwards medium (modified) with additional 5-7\% bovine blood, TSA, and blood agar plates, then the streaked plates were incubated at $37^{\circ} \mathrm{C}$ for 48 hours. Pure bacterial isolates were identified according to their cultural, morphological, and biochemical characteristics (Holt et al., 1994).

\section{Identification of Streptococcus species}

All purified isolates were identified by studying colony growth characteristics ,morphological analysis (Cruickshank et al, 1975), biochemical analysis as catalase activity test, oxidase test, detection of hemolysis, growth at $6.5 \% \mathrm{NaCl}$, growth at $10^{\circ} \mathrm{C}$ and $45^{\circ} \mathrm{C}$, detection of arginine decarboxylase (ADH), hippurate hydrolysis test, bile esculin test, fermentation of sugers (MacFaddin, 2000) and multiplex polymerase chain reaction (m- PCR) for detection of some pathogenic bacteria directly from the samples and from isolates The extraction of DNA from tested samples was done utilizing the QIAamp DNA small kit (Qiagen, Germany, GmbH) with alterations compared to the manufacturer's suggestions. Briefly, $200 \mu \mathrm{l}$ of the sample suspension tested was incubated for 10 minutes with $20 \mu \mathrm{l}$ proteinase, potassium and $200 \mu \mathrm{l}$ of lysis buffer at $56^{\circ} \mathrm{C}$. After incubation $200 \mu \mathrm{l}$ of $100 \%$ ethanol added to the lysate 1 . The sample was washed and centrifuged according to manufacturer's protocol. The nucleic acid was eluted with $100 \mu$ l elution buffer, which was given within the kit. PCR specific primers from Metabion (Germany, table 1), were used in a 50- $\mu 1$ multiplex PCR response containing $25 \mu \mathrm{l}$ of Emerald Amp Max PCR Master blend (Takara, Japan), $1 \mu$ of each primer of 20 picomols (pmol) concentrations, $11 \mu \mathrm{l}$ water, and $8 \mu \mathrm{l}$ DNA template. The reaction was performed in an applied 2720 thermal cycler biosystem. PCR products were isolated on 1.5\% agarose gel (Applichem, Germany, GmbH) in 
1xTBE buffer at room temperature using 5 Volts/cm slopes by electrophoresis. $40 \mu \mathrm{l}$ of the products were loaded into each gel slot for gel analysis. The part sizes were calculated using Gelpilot 100 base per Ladder (Qiagen, Germany, $\mathrm{GmbH}$ ). The gel documentation system (Alpha Innotech, Biometra) captured the gel and the computer program analyzed the information

Table 1. Primers sequences, target genes, amplicon sizes and cycling conditions.

\begin{tabular}{|c|c|c|c|c|c|c|c|c|c|}
\hline \multirow[b]{2}{*}{$\begin{array}{l}\text { Target } \\
\text { Agent }\end{array}$} & \multirow[b]{2}{*}{$\begin{array}{l}\text { Target } \\
\text { gene }\end{array}$} & \multirow[b]{2}{*}{ Primers sequences } & \multirow{2}{*}{$\begin{array}{c}\text { Amplified } \\
\text { segment } \\
\text { (base per) }\end{array}$} & \multirow[b]{2}{*}{$\begin{array}{c}\text { Primary } \\
\text { denaturation }\end{array}$} & \multicolumn{3}{|c|}{ Amplification (35 cycles) } & \multirow[b]{2}{*}{$\begin{array}{c}\text { Final } \\
\text { extension }\end{array}$} & \multirow[b]{2}{*}{ References } \\
\hline & & & & & \begin{tabular}{|c|} 
Secondary \\
denaturation
\end{tabular} & Annealing* & Extension & & \\
\hline \multirow{3}{*}{ E. faecalis } & \multirow{3}{*}{$\begin{array}{c}16 \mathrm{~S} \\
\text { rRNA }\end{array}$} & GTT TAT GCC GCA TGG CAT & \multirow{3}{*}{310} & \multirow{10}{*}{$\begin{array}{c}94^{\circ} \mathrm{C} \\
5 \text { minutes }\end{array}$} & \multirow{10}{*}{$\begin{array}{c}94^{\circ} \mathrm{C} \\
30 \text { seconds }\end{array}$} & \multirow{10}{*}{$\begin{array}{c}50^{\circ} \mathrm{C} \\
40 \text { seconds }\end{array}$} & \multirow{10}{*}{$\begin{array}{c}72^{\circ} \mathrm{C} \\
45 \text { seconds }\end{array}$} & \multirow{3}{*}{\multicolumn{2}{|c|}{$\begin{array}{l}\text { Zoletti et al., } \\
2006\end{array}$}} \\
\hline & & AAG AG & & & & & & & \\
\hline & & $\begin{array}{c}\text { CCG TCA GGG GAC GTT } \\
\text { CAG }\end{array}$ & & & & & & & \\
\hline \multirow{3}{*}{ S. agalactiae } & \multirow{3}{*}{$\mathrm{cfb}$} & TTTCACCAGCTGTATTAGAA & \multirow{3}{*}{153} & & & & & \multirow{3}{*}{$\begin{array}{c}72^{\circ} \mathrm{C} \\
10 \text { minutes }\end{array}$} & \multirow{3}{*}{$\begin{array}{l}\text { Ke et al., } \\
2000\end{array}$} \\
\hline & & GTA & & & & & & & \\
\hline & & $\begin{array}{c}\text { GTTCCCTGAACATTATCTTT } \\
\text { GAT }\end{array}$ & & & & & & & \\
\hline \multirow{4}{*}{ E. faecium } & \multirow{4}{*}{ sodA } & GAAAAAACAATAGAAGAAT & & & & & & & \multirow{4}{*}{$\begin{array}{l}\text { Jackson et } \\
\text { al., } 2004\end{array}$} \\
\hline & & TAT & 215 & & & & & & \\
\hline & & $\overline{\text { TGCTTTTTTGAATTCTTCTTT }}$ & 215 & & & & & & \\
\hline & & $\mathrm{A}$ & & & & & & & \\
\hline
\end{tabular}

*The annealing temperature of the primers was modified, and validated to $50^{\circ} \mathrm{C}$ to be suitable for multiplex PCR.

\section{Biochemical examinations}

The fish body surfaces were cleaned and dried with absorbent paper. Blood samples obtained from caudal vessels of $2 \mathrm{ml} /$ fish from each farm using disposable 3 milliliters syringes, were transferred to serum separation tubes without anticoagulants, such as defined for total serum protein, albumin, globulin, total cholesterol, urea, creatinine levels, and AST, ALT, ALP, GPX, CAT, SOD activities, which were estimated spectrophotometrically (LABOMED Co., Lab. American Inc., USA) according to the manufacturer's instructions.

\section{RESULTS}

Table 2. Water quality parameters in examined tilapia fish farms $(n=20)$ at different locations in Kafr El sheikh Governorate, Egypt

\begin{tabular}{lcc}
\hline Parameters & Values & Permissible limit* $^{*}$ \\
\hline $\mathrm{pH}$ & $8.2 \pm 0.73$ & $6.5-9$ \\
Dissolved oxygen (ppm) & $7.44 \pm 0.54$ & $5.61-9.4$ \\
Unionized ammonia (ppm) & $0.05 \pm 0.008$ & $0.00-0.02$ \\
Nitrite (ppm) & 0.00 & $0.00-0.2$ \\
\hline
\end{tabular}

Values are means \pm standard error. *Permissible limit according to Egyptian law No. 48 (1982).

\section{Clinical and post mortem examinations}

The samples of infected fishes revealed the presence of eye lesions (bilateral exophthalmia and opacity), skin lesions and congestion of the internal organs (Figures 1 and 2).

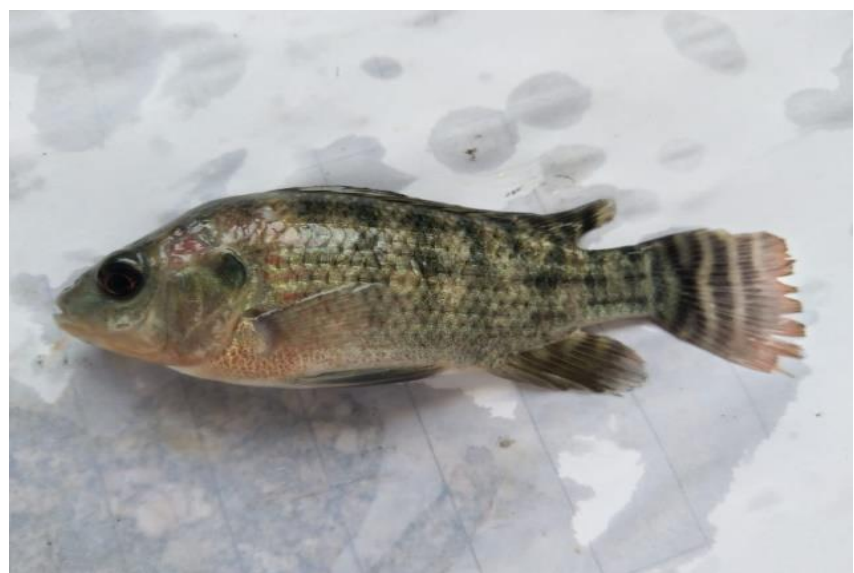

Figure 1. Bilateral exophthalmia and skin lesion in tilapia fish

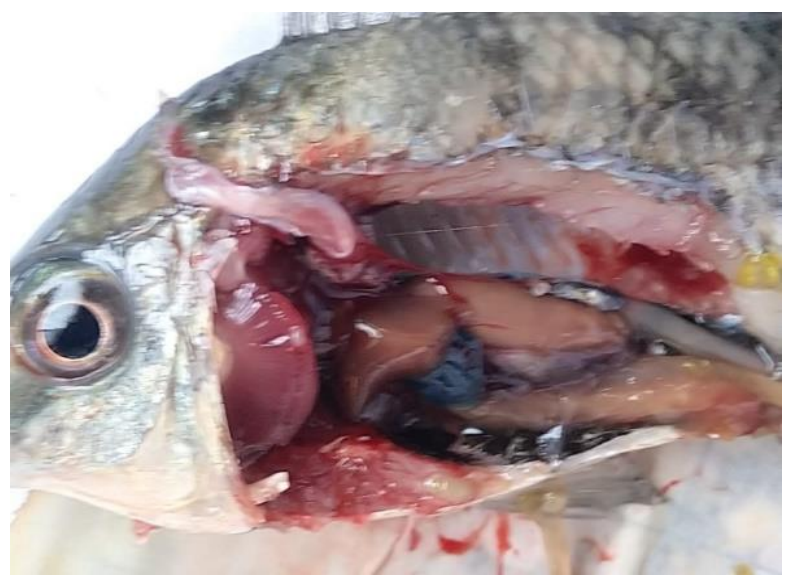

Figure 2. Congestion of the internal organs in tilapia fish 
Table 3. Percentage of positive Streptococcus species isolated from tilapia fish $(\mathrm{n}=100)$ and water samples $(\mathrm{n}=20)$ was done at the Animal Health Institute - Kafer El sheikh Regional Laboratory, in Egypt and in summer 2018.

\begin{tabular}{lccc}
\hline Samples types & Samples number & Positive samples number & Percentage $(\%) *$ \\
\hline Tilapia fish samples & 100 & 38 & 38 \\
Water samples & 20 & 8 & 40 \\
\hline *Percentage (\%) calculated according to total number of samples. & &
\end{tabular}

Table 4. Identification of Streptococcus species isolated from positive tilapia fish samples was done at the Animal Health Institute - Kafer El sheikh Regional Laboratory, in Egypt and in summer 2018.

\begin{tabular}{lcc}
\hline Identified organism & \multicolumn{2}{c}{$\begin{array}{c}\text { Positive samples } \\
(\mathbf{n}=\mathbf{3 8})\end{array}$} \\
\hline Enterococcus faecalis & 25 & 65.78 \\
Streptococcus pyogenes & 39.47 \\
Enterococcus faecium & 15 & 6 \\
Streptococcus agalactiae & 15.78 \\
Streptococcus iniae & 5.15 & 3 \\
\hline
\end{tabular}

*Percentage (\%) calculated according to the number of positive fish samples (38).

Table 5. Identification of Streptococcus species isolated from positive farms water samples from four different farms in Kafer El sheikh Governorate, in Egypt and in summer 2018

\begin{tabular}{lcc}
\hline Identified organism & $\begin{array}{c}\text { Positive samples } \\
(\mathbf{n = 3 8})\end{array}$ & Percentage (\%)* \\
\hline Enterococcus faecalis & 7 & 87.5 \\
Streptococcus agalactiae & 3 & 37.5 \\
Streptococcus pyogenes & 2 & 25 \\
Enterococcus faecium & 2 & 25 \\
Streptococcus iniae & 1 & 12.5 \\
\hline
\end{tabular}

*Percentage (\%) calculated according to the number of positive water samples (8).

\section{Detection of some Streptococcus species by using multiplex Polymerase Chain Reaction}

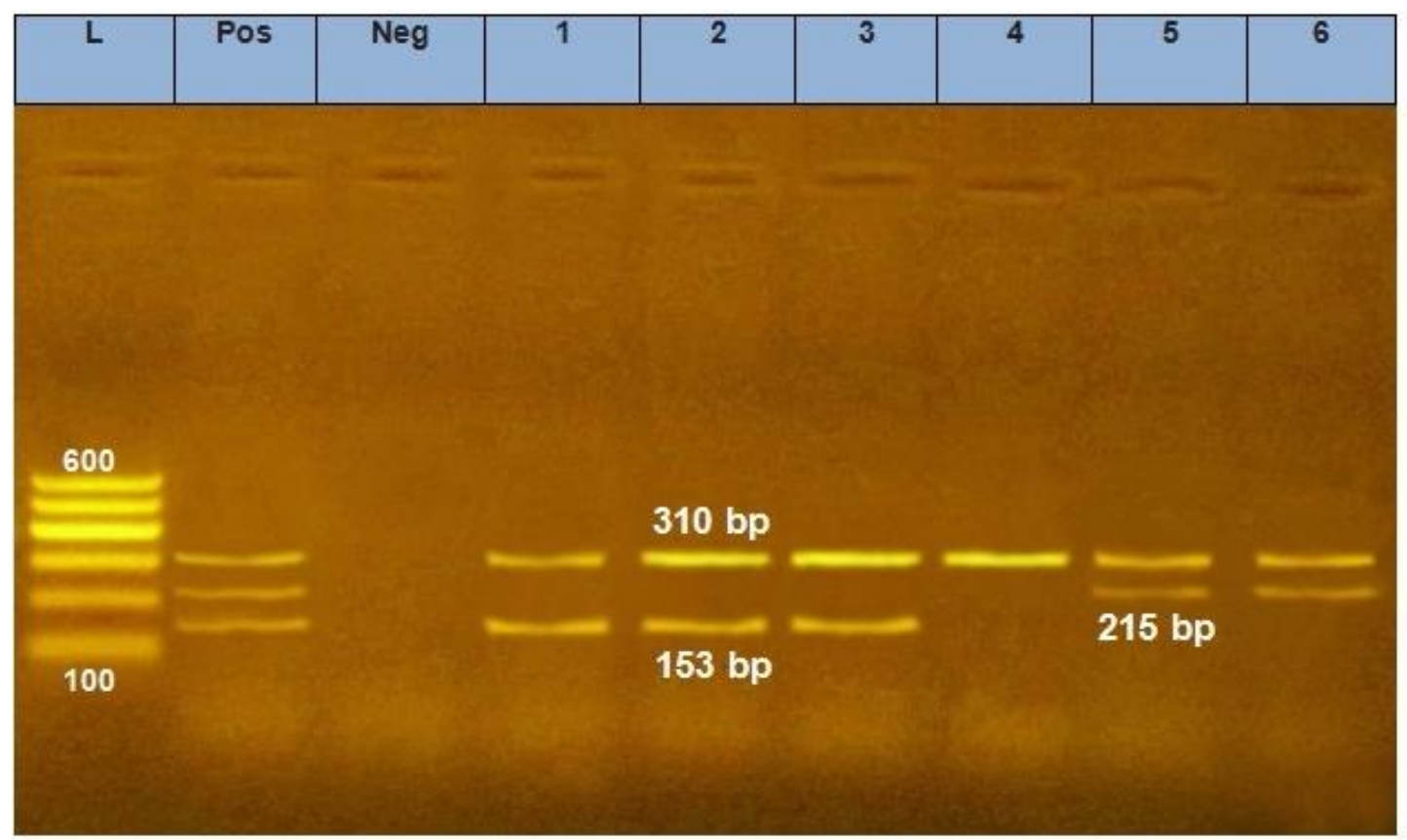

Figure 3. Agarose gel electrophoresis of multiplex PCR amplification products of Streptococcus isolated from tilapia fish samples and water samples. Lane L: 100 base per (bp) ladder as a molecular size DNA marker. Lane Pos: Control positive streptococcus species genes. Lane Neg: Control negative. Lanes1, 2, and 3: Positive for Enterococcus faecalis at 310 bp, and Streptococcus agalactiae at $153 \mathrm{bp}$. Lane 4: Positive for Enterococcus faecalis at $310 \mathrm{bp}$. Lanes 5 and 6: Positive for Enterococcus faecalis at $310 \mathrm{bp}$ and Enterococcus faecium at $215 \mathrm{bp}$. 


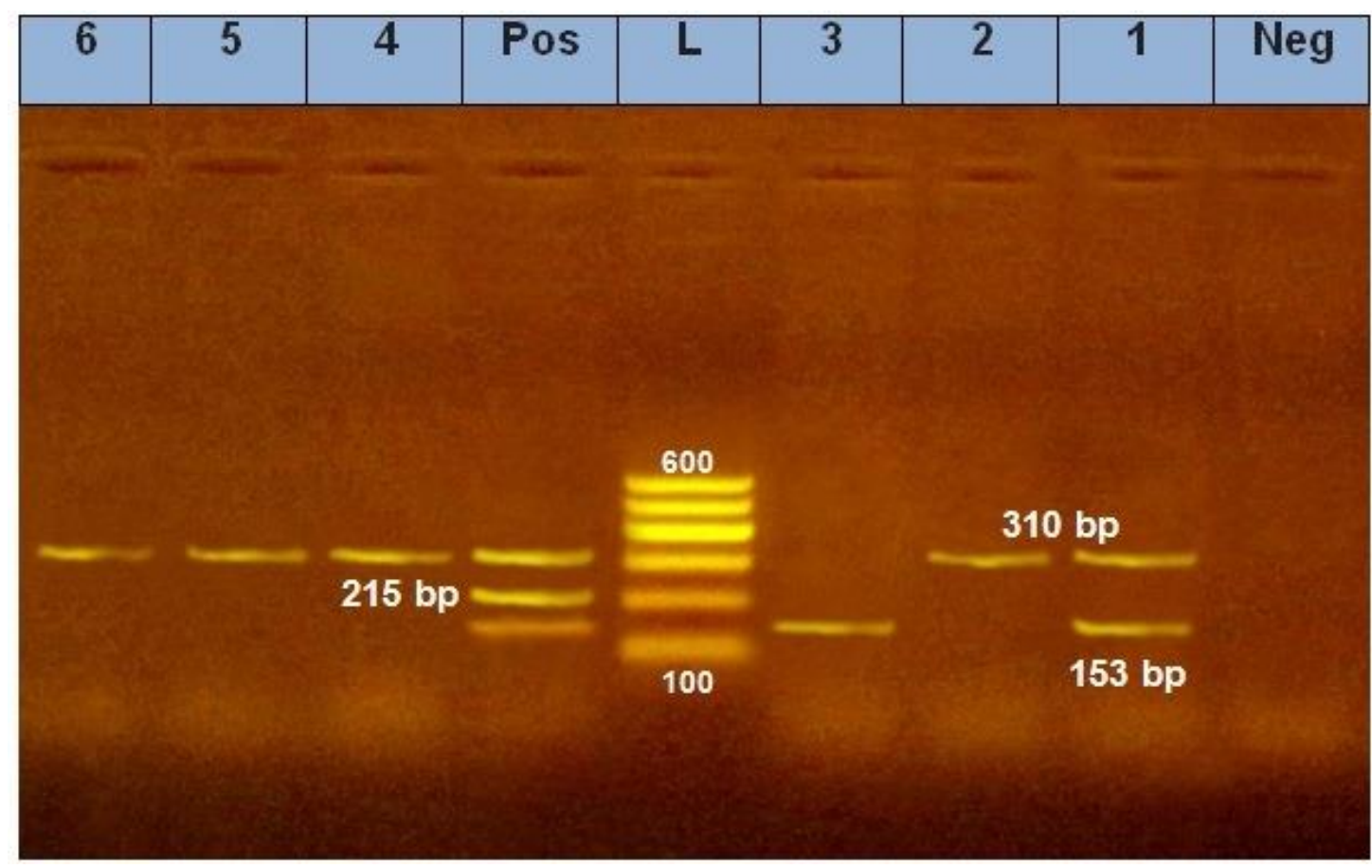

Figure 4. Agarose gel electrophoresis of multiplex PCR of Streptococcus species directly from organs of tilapia fish and water samples. Lane L: 100bp ladder as a molecular size DNA marker. Lane Pos: Control positive Streptococcus species genes. Lane Neg: Control negative. Lane1: Positive for Enterococcus faecalis at $310 \mathrm{bp}$ and Streptococcus agalactiae at 153 bp. Lanes 2, 4, 5 and 6: Positive for Enterococcus faecalis at 310 bp. Lane 3: Positive for Streptococcus agalactiae at $153 \mathrm{bp}$.

Table 6. Variation of some blood serum parameters of Nile tilapia on exposure to Streptococcus infection in Kafer El sheikh Governorate, Egypt

\begin{tabular}{lcc}
\hline Parameters & Non infected & Infected \\
\hline Total protein $(\mathrm{g} / \mathrm{dl})$ & $6.01 \pm 0.08$ & $5.81 \pm 0.05$ \\
Albumin $(\mathrm{g} / \mathrm{dl})$ & $5.44 \pm 0.03$ & $5.21 \pm 0.09$ \\
Globulin $(\mathrm{g} / \mathrm{dl})$ & $0.76 \pm 0.11^{\mathrm{a}}$ & $0.40 \pm 0.08^{\mathrm{b}}$ \\
Urea $(\mathrm{mg} / \mathrm{dl})$ & $4.99 \pm 0.05^{\mathrm{b}}$ & $5.12 \pm 0.02^{\mathrm{a}}$ \\
Creatinine (mg/dl) & $1.89 \pm 0.08$ & $1.99 \pm 0.03$ \\
AST $(\mathrm{u} / \mathrm{ml})$ & $31.3 \pm 0.46^{\mathrm{b}}$ & $47.3 \pm 0.38^{\mathrm{a}}$ \\
ALT $(\mathrm{u} / \mathrm{ml})$ & $54.3 \pm 0.27^{\mathrm{b}}$ & $82.3 \pm 1.2^{\mathrm{a}}$ \\
ALP $(\mathrm{u} / \mathrm{ml})$ & $76.3 \pm 0.27$ & $74.8 \pm 0.61$ \\
Glucose $(\mathrm{mg} / \mathrm{dl})$ & $159.4 \pm 0.54^{\mathrm{b}}$ & $235.7 \pm 0.27^{\mathrm{a}}$ \\
Cholesterol (mg/dl) & $176.75 \pm 1.67^{\mathrm{b}}$ & $192.02 \pm 1.23^{\mathrm{a}}$ \\
Cortisol $(\mathrm{ng} / \mathrm{ml})$ & $2.9 \pm 0.11^{\mathrm{b}}$ & $3.36 \pm 0.12^{\mathrm{a}}$ \\
\hline
\end{tabular}

Values are means \pm standard error. Means inside the same row of diverse litters are essentially distinctive at $\mathrm{p} \leq 0.05$.

Table 7. Variation of some blood serum antioxidant enzymes of Nile tilapia on exposure to Streptococcus infection in Kafer El sheikh Governorate, Egypt

\begin{tabular}{|c|c|c|}
\hline Items & Non infected & Infected \\
\hline Glutathione peroxidase $(\mathrm{GPX})(\mathrm{u} / \mathrm{ml})$ & $16.6 \pm 1.21^{\mathrm{b}}$ & $21.6 \pm 1.11^{\mathrm{a}}$ \\
\hline Catalase(CAT) (u/ml) & $12 \pm 0 .{ }^{06 \mathrm{~b}}$ & $19 \pm 0.03^{\mathrm{a}}$ \\
\hline Superoxide dismutase (SOD) $(\mathrm{u} / \mathrm{ml})$ & $200.62 \pm 0.22^{\mathrm{b}}$ & $282.58 \pm 0.11^{\mathrm{a}}$ \\
\hline
\end{tabular}

Values are means \pm standard error. Means within the same row with different litters are significantly different at $\mathrm{p} \leq 0.05$.

\section{DISCUSSION}

Streptococcal infections have been frequently reported in the freshwater and saltwater fish that have been cultivated in several regions of the world, particularly tilapia species, and several Streptococcus species were involved (Chang and Plumb, 1996). The most effective Streptococcus species in fish are S. iniae, S. difficile, S. agalactiae, S. parauberis, S. dysgalactiae and S. Shiloi (Eldar et al., 1995; Mata et al., 2004; Netto et al., 2011). S. agalactiae belongs to group B streptococci, which may be either haemolytic (Evans et al., 2002) or non-haemolytic (Finch and Martin, 1984) .All eight strains of $S$. agalactiae isolated from tilapias are non-haemolytic. S. agalactiae is really the only streptococcal species which belongs to the Lancefield serotyping sero-group B (Devriese et al., 1991). 


\section{Water quality parameters}

Natural conditions encompassing the cultural areas could influence the water quality and introduce stress to the cultivated fish. This inevitably diminishes the immune status, and activates bacterial disease which leads to infection (Amal et al., 2015).

The results of the analysis of water quality parameters shown in table 2 revealed that the mean value of $\mathrm{pH}$, dissolved oxygen, unionized ammonia and nitrite were $8.2 \pm 0.73,7.44 \pm 0.54,0.05 \pm 0.008$ parts per million (ppm) and $0.00 \mathrm{ppm}$, respectively. Our results indicated that some parameters of water quality, like water $\mathrm{pH}$, dissolved oxygen, and nitrite, were within the recommended range for tilapia cultivation, but ammonia was higher than the recommended range for tilapia culture. These results were similar to those studied by Zamri-Saad et al. (2014) and lower than those reported by Ali et al. (2008).

The ammonia in water samples is assumed to originate from the feces of fish and excessive feed provided to the fish. Tilapias can live in $\mathrm{pH}$ extending between 5 and 10, but grow best at $\mathrm{pH}$ levels between 6 and 9 (Popma and Masser, 1999). But on the other hand, a low $\mathrm{pH}$ of the water contributed to behavioral changes, damage to the gill epithelial cells, and a reduced nitrogen excretion efficiency, and causes high mortality (Sammut, 2001).

Non-ionized ammonia is the most poisonous fish parameter in the aquaculture and contaminated water (Zhao et al., 1997; Harris et al., 1998; El-Shafai et al., 2004). In fresh water, the toxic levels for free ammonia in short-term exposure were usually between 0.6 and $2 \mathrm{mg} / \mathrm{l}$, while others consider $0.1 \mathrm{mg} / \mathrm{l}$ as the highest tolerable concentration (Pillay, 1992).

The present study also identified the significant parameters of water quality that affected the presence of the bacteria in cultivated fish. Although each sampling site has a different parameter of water quality related to the presence of bacteria, ammonia and nitrite are two of the major important contaminants that threaten the health of aquatic organisms, particularly in freshwater, and have since been described as the most important parameters, that there are strong associations with the presence of bacteria at all sampling.

Popma and Masser (1999) recorded that metabolism, growth, and resistance disease were impaired if Dissolved Oxygen declines over an extended period and tilapias predisposed to streptococcosis. In addition (Swann, 1992; ElSayed, 2006) studied that, the concentration of dissolved oxygen higher than $5 \mathrm{ppm}$ is necessary for good growth of tilapia. Nitrite is extremely toxic to tilapia as it disrupts the fish's physiological function and results in growth retardation, as reported by El Sayed, (2006). Nitrite could inactively enter the circulatory system as a nitrous acid and diffused unconditionally through the layers of fish gills. Upon entering the circulation system, nitrite oxidizes the iron within the hemoglobin particle from ferrous state $(\mathrm{Fe} 2+)$ to ferric state $(\mathrm{Fe} 3+)$ and the resulting product is called methemoglobin. Because methemoglobin is unable to reversibly combine with oxygen, exposure to nitrite can lead to significant respiratory trouble since even the blood's oxygen-carrying capacity is difficult (Boyd and Tucker, 1998).

\section{Isolation and identification of Streptococcus species}

In table 3, data revealed that Streptococcus species were isolated from 100 diseased tilapia fish, since 38 samples showed an incidence of $38 \%$, while 20 water samples showed 8 positive Streptococcus isolation with an incidence of 40\%. These findings were lower than those mentioned by Asencios et al. (2016) and El-refaee (2005), who isolated Streptococcus species with the percentage of $100 \%$ and $39.8 \%$, respectively from tilapia fish. The recorded results were higher by El-Rouhy (2002) in Sharkia and Ismailia (21.8\%), Zeid (2004) in El-Mansoura city (18\%), and Huang et al. (1991) in marine water fish (17.3\%). Also, the recorded results were higher than reported by Badran and Eissa (1991), who mentioned that incidence of Streptococcus was $1.7 \%$ in tilapia. The incidence of Streptococcus was reported by ElBouhy and Megaheed (1994) 9.2\% and 10\% in cultivated Oreochromis niloticus by Ebtsam (2002). The different percentage of streptococcal infection could be attributed to different fish species and different environmental factors as well as the use of manure and waste water beside chicken and duck houses over fish ponds.

The tables 4 and 5 of the present study showed the identification of Streptococcus species isolated from positive tilapia fish samples and water. The proportions of fish and water samples were $65.78 \%$ and $87.5 \%$ for Enterococcus faecalis, $39.47 \%$ and $25 \%$ for Streptococcus pyogenes, $15.78 \%$ and 25\% for Enterococcus faecium, $13.15 \%$ and $37.5 \%$ for Streptococcus agalactiae, and finally $7.89 \%$ and $12.5 \%$ for Streptococcus iniae respectively. The percentage of isolation of Enterococcus faecalis and Streptococcus pyogenes from fish was found to be higher than those reported by Abou El-gheit (2005), Amal (2009), Khafagy et al. (2009) and Osman et al. (2017). The Enterococcus faecalis isolated from tilapia fish with the percentages of 7.5\%, 45\%, 5\%, and 23.76\% and Abou El-gheit (2005) isolated Streptococcus E. pyogenes with a percentage of $16 \%$, while the percentage of isolation of Enterococcus faecium ,Streptococcus agalactiae and Streptococcus iniae from fish were lower than the percentage which reported by Asencios et al. (2016), who isolated Streptococcus agalactiae from fish at 56.3\%, but Amal (2009) isolated Streptococcus iniae with 32.4\%, while the results of the present study was similar to Delphino et al. (2019), who isolated Streptococcus agalactiae from fish with $16 \%$ and Hernández et al. (2009) with 17.5\% from fish. Although Saleh et al. (2019) isolated Streptococcus iniae with $13.3 \%$ from fish. 
Diagnostic techniques to detect pathogenic bacteria responsible for the streptococcosis of fish are usually based on the cultured technique, which takes many days to reach a final diagnosis leading to an increased disease outbreak potential. PCR can target unique genetic sequences of microorganisms and has been previously developed to detect pathogenic fish bacteria using a primer specific that is specific for a gene segment of a particular bacterium (Mata et al., 2004).

In the present study, the multiplex PCR test for the detection of streptococcosis caused by E. faecalis, S. agalactiae, and E. faecium was proposed, which could cause great losses and could be a threat to the fish farmers. All primers were used to detect these pathogenic bacteria isolated from infected fish cultured (Ke et al., 2000; Jackson et al., 2004). The m-PCR was accurate and specific for the detection of representative pure isolates of E. faecalis, S. agalactiae, and E. faecium with the detection limits.

\section{Molecular identification}

In the present study, PCR was used to identify the isolates using species-specific primers. The majority of the isolates from the previously mentioned specimens were E. faecalis (6 of 6) with the percentage of $100 \%$, followed by $S$. agalactiae (3 of 6) with the percentage of 50\%, and E. faecium ( 2 of 6) with the percentage of 33.3\%. However, Ouissal et al. (2015) detected E. faecium from European sea bream as the most frequently isolated species of Enterococcus with the percentage of $24.32 \%$, followed by $18.91 \%$ to E. faecalis, while Qasem et al. (2008) found that most of the isolates from fishes and wastewater samples (9 out of 17) with the percentage of $52.94 \%$ were identified as S. agalactiae.

By detecting warm-water streptococcosis, the sensitivity threshold for the identification of S. iniae, S. difficilis, S. parauberis, and L. garvieae was between $2.5 \times 10^{3}$ and $1.2 \times 10^{4}$ cells/g tissue (Mata et al., 2004). Although the sensitivity of m-PCR to the detection of specific bacteria from fish tissue was not fulfilled, the m-PCR analysis in this study allowed the detection of S. agalactiae (5 of 6) with the percentage of $83.3 \%$ and E. faecalis (2 of 6$)$ with the percentage of $33.33 \%$, directly from the infected tilapia organs (Itsaro et al., 2012).

\section{Biochemical parameters associated with streptococci infection}

The present experiment was conducted to diagnose of Streptococcus infection using the estimation of water quality parameters and biochemical parameters, since diagnostic techniques for the detection of pathogenic bacteria responsible for fish streptococcosis are usually based on the cultured technique, which requires many days to reach a proper diagnosis leading to the increased potential for a disease outbreak. In tilapia fish, biochemical changes were studied to identify the variable parameters for the determination of healthy and infected fishes.

In table 6 the results of the present study revealed that there were insignificantly decreased in total protein and albumin but there was significant decreased in globulin, also there were significant increase in total cholesterol, urea, creatinine levels, and AST, ALT, GPX, CAT, SOD activities compared to non-infected fish. These results were similar to recorded by Adel and Shalaby (2004) and Yu et al. (2010), who revealed that decrease of serum total protein could be due to increased protein breakdown as a stimulator of corticosteroid hormones, which enhances proteins breakdown to provide amino acids and gluconeogenesis to provide glucose to cope with the increase in energy demands to balance stressful condition. Elevated Creatinine and urea levels may also be associated with reduced kidney function (Zotti et al., 2008) and as an indication of gill and kidney dysfunction (Adham et al., 2002; Yang and Chen, 2003). The increase in ALT and AST levels was similar to studies by Chen et al., (2004), Abuseliana et al., (2010), Bin and Xiao-jin, (2010) and Khalil et al., (2011). The increased level of these parameters due to infection were suggested to be due to the severe damage of viscera organs such as liver and kidney. There were no changes in alkaline phosphatase enzyme between infected and uninfected fishes, these differed from those reported by chen et al. (2011), who studied that alkaline phosphatase was significantly increased 12 hours post-infection with streptococcus iniae. Elevated cholesterol and glucose levels could be associated with the stress response and metabolism. These results were consistent with previous findings from Alsaid et al. (2014) and a similar increase in blood glucose levels had been detailed by Evans et al. (2006) taken after exposure of (O. niloticus) Nile tilapia to unionized ammonia. These elevated glucose levels may be due to the decrease in insulin levels, since insulin has a greater influence on protogenic and lipogenic pathways (El- Naggar et al., 1998). Also, the results of the present experiment revealed that there was a significant increase in cortisol levels in an infected group than in the uninfected group. These results were similar to those of Qiang et al., (2016), which increased the level of ammonia serve as acute stress and secrete a high amount of cortisol to facilitate the synthesis of glucose and degradation of fat.

In table 7, the results of the present research showed a significant increase in GPX, CAT, and SOD activities compared to non-infected fish. These results were consistent with those examined by Harikrishnan et al. (2012). In addition, malondialdehyde and SOD are example of biomarker for oxidative stress besides catalase (CAT) enzymes, Glutathione Peroxidase (GPx) and Glutathione Reductase (GR). When fish are under stress conditions, the level of Reactive Oxygen Species (ROS) also increases. Defense mechanisms to fight the ROS overload were found in many mammalian species and fish. Thus, fishes are mainly being used as bio indicators for environmental changes (Beutler, 
1984). Catalase is an essential antioxidant defense component, protects fish from oxidative stress by converting the hydrogen peroxide into oxygen and water (Atli and Canli, 2007). SODs are enzymes which then catalyze the dismutation of superoxide $\left(\mathrm{O}^{2-}\right)$ radicals into either conventional atomic oxygen $\left(\mathrm{O}_{2}\right)$ or hydrogen peroxide $\left(\mathrm{H}_{2} \mathrm{O}_{2}\right)$. Superoxide is a by-product of oxygen metabolism and causes many types of cell damage if not regulated (Garry, 2011; Tohru and Masuko, 2011).

\section{CONCLUSION}

Tilapia has become a perfect host for Streptococcus infections. Streptococcus (S. agalactiae and $S$. iniae) are exceptionally pathogenic since they can infect many spices of fish around the world. Streptococcosis has been found to cause millions of economic losses in aquaculture worldwide. Tilapia farmers should be advised and trained on the proper management of tilapia fish to avoid the spread and outbreak of disease. Furthermore, water quality parameters play a vital role in tilapia farming. In particular, an ideal parameter for water quality should be preserved to avoid "stress" in fish, which could lead to infection events. The diagnosis of diseased and carrier fish could be achieved using fast and accurate molecular techniques and measurement of fish biochemical parameters. Also, the present study demonstrated that the m-PCR assay was a sensitive and specific diagnostic tool for simultaneous detection of fish streptococcosis caused by E. faecalis, S. agalactiae, and E. faecium from fish and water isolates, however only a limited range of isolates could be detected directly from multiplex PCR from fish tissues and water. Although chemotherapy was not really suggested, proper management, and immunization could be aspects of the system to prevent and control streptococcosis.

\section{DECLARATION}

\section{Acknowledgments}

All authors are very grateful to all members of Animal Health Research Institute, Kafr El sheikh branch.

\section{Competing interests}

The authors declare that they have no competing interests.

\section{Author's contribution}

Hala AM Abd El-Hady and Mayada AM Abou Zeid found a research idea, planned the study design, performed data, the bacteriological and_molecular_examinations, and drafted the manuscript. Gehan IE Ali shared the research's idea, shared designed work, and shared a collection of blood samples during the experiment and helped the manuscript preparation. All authors have read and approved the final manuscript.

\section{REFERANCES}

Aboyadak IM, Sabry NM, Ali NG and El-Sayed HS (2016). Isolation of Staphylococcus epidermidis, Bacillus cereas and, Pseudomonas stutzeri from diseased European sea bass (Dicentrarchus labrax) for the first time in Egypt. Egyptian Journal of Aquatic Biology and Fisheries, 20(4): 103114. DOI: https://doi.org/10.21608/ejabf.2016.11182

Abou El-gheit EN (2005). Some investigations on the role of water parameters in microbial infections of fishes. Egyptian Journal of Expression Biology (Zoology), 1: 9-14. Available at: http: //www.egyseb.net/ejebz/index.php?mno=187306

Abuseliana A, Daud H, Aziz SA, Bejo SK, and Alsaid M (2010). Streptococcus agalactiae the etiological agent of mass mortality in farmed Red Tilapia (Oreochromis sp.). Journal of Animal and Veterinary Advanced, 9(20): 2640-2646: Available at: https://www.cabdirect.org/cabdirect/abstract/20103364088.

Adel ME, Shalaby (2004). The opposing effect of ascorbic acid (vitamin C) on ochratoxin toxicity in Nile tilapia (Oreochromis niloticus). In: Proceedings of the 6th International Symposium on Tilapia in Aquaculture (R.B. Remedios, G.C. Mair and K. Fitzsimmons, editions), pp. 209221. Available at: https://cals.arizona.edu/oip/ista6/ista6web/pdf/209.pdf .

Adham KG, Ibrahim HM, Hamed SS, and Saleh RA (2002). Blood chemistry of the Nile tilapia, Oreochromis niloticus (Linnaeus, 1757). Aquatic Ecology, 36: 549-557. Available at: https://link.springer.com/content/pdf/10.1023/A:1021137122046.pdf

Al-Harbi AH, Uddin MN (2004). Seasonal variation in the intestinal bacterial flora of hybrid tilapia (Oreochromis cultured in earthen ponds in Saudi Arabia. Aquaculture, 229: 37-44. DOI: https://doi.org/10.1016/S0044-8486 (03)00388-0

Ali FK, El-Shafai SA, Samhan FA, and Khalil WK (2008). Effect of water pollution on expression of immune response genes of Solea aegyptiaca in Lake Qarun. African Journal of Biotechnology, 7(10): 1418-1425. Available at: http://www.academicjournals.org/AJB

Alsaid M, Abuseliana AF, Daud HH, Mustapha NM, Bejo SK, Abdelhadi YM, and Hamdan RH (2014). Haematological, biochemical and clinical signs changes following experimental infection of Streptococcus agalactiae in red hybrid tilapia (Oreochromis sp.). Aquacultura Indonesiana, 15(2): 86-93. DOI: http://dx.doi.org/10.21534/ai.v15i2.36

Atli G, and Canli M (2007). Enzymatic responses to metal exposures in a freshwater fish Oreochromis niloticus, Comparative Biochemistry and Physiology part C, 145: 282-287. DOI: https://doi.org/10.1016/j.cbpc.2006.12.012

Amal MAK (2009). Bacteriological and molecular studies on the streptococci isolated from diseased fish. ph.D. A Thesis in Microbiology. Faculty of Veterinary Medicine. Alexandria University.

Amal MNA (2011). Prevalence, risk factors and transmission of Streptococcus agalactiae in the red hybrid tilapia (Oreochromis sp.). Ph.D thesis, Faculty of Veterinary Medicine, Universiti Putra Malaysia, Serdang, pp. 161-214. Available at: http://psasir.upm.edu.my/id/eprint/70094/1/FPV\%202011\%2017\%20-\%20IR.pdf 
Amal MNA, and Zamri-Saad M (2011). Streptococcosis in tilapia (Oreochromis niloticus): a review. Pertanika Journal of Tropical Agriculture Science, 34(2): 195-206. Available at: http://psasir.upm.edu.my/id/eprint/58202/1/JTAS\%20Vol.\%2034\%20\%282\%29\%20Aug.\%202011\%20\%28View\%20Ful1\%20Journal\%29.pdf\# page $=8$

Amal MNA, Zamri-Saad M, Siti-Zahrah S and Zulkafli AR (2015). Water quality influences the presence of Streptococcus agalactiae in cage cultured red hybrid tilapia, Oreochromis niloticus $\times$ Oreochromis mossambicus. Aquaculture Reseach, 46 (2): $313-323 . \quad$ DOI: https://doi.org/10.1111/are.12180

American Public Health Association (APHA) (1998). Standard methods for the examination of water and wastewater, 23rd edition, Washington. Available at: https://yabesh.ir/wp-content/uploads/2018/02/Standard-Methods-23rd-Perv.pdf

Anshary H, Kurniawan RA, Sriwulan S, Ramli R, and Baxa DV (2014). Isolation and molecular identification of the etiological agents of streptococcosis in Nile tilapia (Oreochromis niloticus) cultured in net cages in Lake Sentani, Papua, Indonesia. Springer Plus, 3(1): 627. Available at: http://www.springerplus.com/content/3/1/627

Asencios YO, Sánchez FB, Mendizábal HB, Pusari KH, Alfonso HO, Sayán AM, and Chaupe NS (2016). First report of Streptococcus agalactiae isolated from Oreochromis niloticus in Piura, Peru: Molecular identification and histopathological lesions. Aquaculture Reports, 4: 74-79. DOI: https://doi.org/10.1016/j.aqrep.2016.06.002

Azad IS, Rajendran KV, Rajan JJS, Vijayan KK, and Santiago TC (2001). Virulence and histopathology of Aeromonas hydrophila (SAH 39) in experimentally infected tilapia Oreochromis mossambicus (L.). Journal of Aquatic Tropica, 16: 265-275. Available at: https://www.researchgate.net/publication/216522174

Badran AF, and Eissa IA (1991). Studies on bacterial diseases among cultured fresh water fish (Oreochromis niloticus) in relation to the incidence of bacterial pathogens at Ismailia Governorate. Journal of Egyptian Veterinary Medical Association, 51 (4): $837-847$.

Beutler E (1984). A manual of biochemical methods. In: Beutler, (Edition.), Red cell metabolism. Greene and Straton Publishers, Philadelphia, pp. 72136. Available at: https://www.semanticscholar.org/paper/Red-Cell-Metabolism\%3A-A-Manual-of-Biochem

Bin X, and Xiao-jin X (2010). Studies on blood chemistry indices and histopathology of Pseudosciaena crocea artificially challenged with Vibrio harveyi. Journal of Fisheries. China, 34 (4): 618. Available at: https://www.cabdirect.org/cabdirect/abstract/20103175002

Blaxhall PC (1972). The haematological assessment of the health of freshwater fish: a review of selected literature. Journal of fish biology, 4(4): 593604. DOI: https://doi.org/10.1111/j.1095-8649.1972.tb05704.x

Boyd CE, and Tucker CS (1998). Pond aquaculture water quality management. Massachusetts, Kluwer Academic Publisher. Available at: https://link.springer.com/chapter/10.1007/978-1-4615-5407-3_2

Bunch EC, and Bejerano Y (1997). The effect of environmental factors on the susceptibility of hibrid tilapia Oreochromis niloticus x Oreochromis aureus to streptococcosis. Israeli Journal of Aquaculture, 49: 67-76. Available at: https://ci.nii.ac.jp/naid/10027122842/

Cai WQ, LI SF, and MA JY (2004). Diseases resistance of Nile tilapia (Oreochromis niloticus), blue tilapia (Oreochromis aureus), and their hybrid (female Nile tilapia x male blue tilapia) to Aeromonas sobria. Aquaculture, 229(1-4): 79-87. DOI: https://doi.org/10.1016/S0044-8486 (03)00357-0

Chang PA, and Plumb JA (1996). Histopathology of experimental Streptococcus spp. infection in tilapia, Orochromis niloticus (L.), and channel catfish, Ictafurus punctatus (Ratinesque). Journal of Fish Diseases, 19(3): 235-241. DOI: https://doi.org/10.1111/j.1365-2761.1996.tb00130.x

Chen CY, Wooster GA, Getchell RG, Bowser PR, and Timmons MB (2003). Blood chemistry of healthy, nephrocalcinosis-affected and ozonetreated tilapia in a recirculation system, with application of discriminant analysis. Aquaculture, 218(1-4): 89-102. DOI: https://doi.org/10.1016/S0044$\underline{8486}(02) 00499-4$

Chen CY, Wooster GA, and Bowser PR (2004). Comparative blood chemistry and histopathology of tilapia infected with Vibrio vulnificus or streptococcus iniae or exposed to carbon tetrachloride, gentamicin, or copper sulphate. Aquaculture, 239: 421-443. DOI: https://doi.org/10.1016/j.aquaculture.2004.05.033

Chen J, Zang X, Qu J, Hu G, Meng S, and Song C (2011). The immune response of tilapia and its susceptibility to Streptococcus iniae under temperature stress. Journal of Agro-Environment Science, $30(9)$ : 1896-1901. Available at: https://www.cabdirect.org/cabdirect/abstract/20123200020

Cruickshank R, Duguid J, Marmion B, and Swain R (1975). Medical Microbiology $12^{\text {th }}$ edition, Edinburg, London and New York.

Delphino MK, Leal CA, Gardner IA, Assis GB, Roriz GD, Ferreira F, and Gonçalves VS (2019). Seasonal dynamics of bacterial pathogens of Nile tilapia farmed in a Brazilian reservoir. Aquaculture, 498:100-108. DOI: https://doi.org/10.1016/j.aquaculture.2018.08.023

Devriese LA, Hommez J, Wijfels R and Haesebrouck F (1991). Composition of the enterococcal and streptococcal intestinal flora of poultry. Journal of Applied Bacteriology, 71(1): 46-50. DOI: https://doi.org/10.1111/j.1365-2672.1991.tb04661.x

Ebtsam SH (2002). Studies on Streptococcosis in Nile tilapia, Oreochromis niloticus, in Assuit (Upper Egypt). Faculty of Veterinary Medicine of Assuit University. M. V. Sc. Thesis.

Egyptian Governmental Law No. 48 (1982). The Implementer Regulations for law 48/1982 regarding the protection of the River Nile and water ways from pollution. Map. Periodical Bulletin, 3-4: 12-35.

El-Bouhy ZM and Megaheed MM (1994). Some bacterial pathogen transmitted by freshwater fish to duckling. Egyptian Journal of Medical Microbiology, 3(3): 430-437.

El-Rouhy M (2002). Studies on streptococcosis in some fresh water fishes in relation to aquatic birds. Ph. D. Thesis Faculty of Veterinary Medicine Zagazig University. https://agris.fao.org/agris-search/search.do?recordID=EG2003001139

Eldar A, Bejerano Y, Livoff A, Horovitcz A and Bercovier H (1995). Experimental streptococcal meningo-encephalitis in cultured fish. Veterinary Microbiology, 43: 33-40. DOI: https://doi.org/10.1016/0378-1135 (94)00052-X

El-Naggar GO, Zaghloul KH, Salah El-Deen MA, and Abo-Hegab S (1998). Studies on the effect of industrial water pollution along different sites of the River Nile on some physiological and biochemical parameters of the Nile Tilapia, Oreochromis niloticus. $4^{\text {th }}$ Veterinary Medicine Zagazig Congress (26-28 August 1998, Hurghada), 713-735.

El-refaee AME (2005). Streptococcus infection in fresh water fish. ph. D. A Thesis in Microbiology. Faculty of Veterinary Medicine, Alexandria University.

El-Sayed AFM (2006). Tilapia culture. Oceanography Department, Faculty of Science, Alexandria University, Egypt. CABI Publishing.

El-Shafai SA, Gijzen HJ, Nasr FA, van der Steen NP, El-Gohary FA (2004). Chronic ammonia toxicity to duckweed-fed tilapia (Oreochromis niloticus). Aquaculture, 232: 117-127. DOI: https://doi.org/10.1016/S0044-8486 (03)00516-7

Evans JJ, Klesius PH, Gilbert PM, Shoemaker CA, Al Sarawi MA, Landsberg J, Duremdez R, Al Marzouk A, and Al Zenki S (2002) .Characterization of b-haemolytic Group B Streptococcus agalactiae in cultured seabream, Sparus auratus L., and wild mullet, Liza klunzingeri (Day), in Kuwait. Journal of Fish Diseases, 25: 505-513. DOI: https://doi.org/10.1046/j.1365-2761.2002.00392.X 
Evans JJ, Pasnik DJ, Brill GC, and Klesius PH (2006). Un-ionized ammonia exposure in Nile Tilapia: toxicity, stress response, and susceptibility to Streptococcus agalactiae. North American journal of aquaculture, 68(1): 23-33. Available at: https://www.tandfonline.com/doi/abs/10.1577/A05-032.1

FAO (2018). The State of World Fisheries and Aquaculture (2018). Meeting the sustainable development goals, p. 23. Rome. Available at: http://www.fao.org/3/i9540en/i9540en.pdf

Farombi EO, Adelowo OA, and Ajimoko YR (2007). Biomarkers of oxidative stress and heavy metal levels as indicators of environmental pollution in African Cat Fish (Clarias gariepinus) from Nigeria Ogun River. International Journal of Environmental Research and Public Health, 4(2): 158165. DOI: https://doi.org/10.3390/ijerph2007040011

Finch LA, and Martin DR (1984). Human and bovine group B streptococci: two distinct populations. Journal of applied bacteriology, 57(2): 273-278 DOI: https://doi.org/10.1111/j.1365-2672.1984.tb01391.x

Garry RB (2011). Superoxide Dismutase in Redox Biology: The roles of superoxide and hydrogen peroxide. Anti-Cancer Agents in Medicinal Chemistry, 11: 341-346. DOI: https://doi.org/10.2174/187152011795677544

Harikrishnan R, Balasundaram C, and Heo MS (2012). Poly D, L-Lactide-co-Glycolic acid-liposome encapsulated odn on innate immunity in epinephelus bruneus against vibrio alginolyticus. Veterinary Immunology and Immunopathology, 147: 77-85. DOI: https://doi.org/10.1016/j.vetimm.2012.04.008

Harris JO, Maguire GB, Edwards S and Hindrum SM (1998). Effect of ammonia on the growth rate and oxygen consumption of juvenile green lip abalone, Haliotis laevigata Donovan. Aquaculture, 160: 259-272. DOI: https://doi.org/10.1016/S0044-8486 (97)00249-4

Hernández E, Figueroa J, and Iregui C (2009). Streptococcosis on a red tilapia, Oreochromis sp., farm: a case study. Journal of fish diseases, 32(3): 247-252. DOI: https://doi.org/10.1111/j.1365-2761.2008.00981.x

Holt JG, Kreig NR, Sneath PHA, Staley JT, and Williams ST (1994). Bergey's Manual of Determinative Bacteriology, 40-169. Williams and Wilkins, Baltimore, USA. Available at: https://www.biodiversitylibrary.org/ia/bergeysmanualofd1957amer/\#page/7/mode/1up

Huang HT, Perng TF, Hsu JP, Hung HH, and Chang RR (1991). Investigation on the diseases of farmed marine fishes in the Pingtung area. Taiwan Journal of Veterinary Medicine and Animal Husbandry. 58: 33-57.

Hubbert RM (1989). Bacterial diseases in warmwater aquaculture. Fish Culture in Warm Water Systems: Problems and Trends, 179-194.

Itsaro A, Suanyuk N, and Tantikitti C (2012). Multiplex PCR for simultaneous detection of Streptococcus agalactiae, Streptococcus iniae and Lactococcus garvieae: a case of S. agalactiae infection in cultured Nile tilapia (Oreochromis niloticus) and red tilapia (Oreochromis niloticus x Oreochromis mossambicus). Songklanakarin Journal of Science and Technology, 34(5): 247-254. Available at: http://rdo.psu.ac.th/sjstweb/journal/34-5/0475-3395-34-5-495-500.pdf

Jackson CR, Fedorka-Cray PJ, and Barrett JB (2004). Use of a genus-and species-specific multiplex PCR for identification of Enterococci. Journal of clinical microbiology, 42(8): 3558-3565. DOI: https://doi.org/10.1128/JCM.42.8.3558-3565.2004

Khalil RH, Hana RE, and Nadia B (2011). Contribution to Vibriosis in cultured eels (Anguilla Anguill). Journal of American Science, 7(12): 101-110.

Ke D, Ménard C, Picard FJ, Boissinot M, Ouellette M, Roy PH, and Bergeron MG (2000). Development of conventional and Real-Time PCR assays for the rapid detection of group B streptococci. Clinical Chemistry, 46(3): 324-331. Available at: https://academic.oup.com/clinchem/article/46/3/324/5641258

Khafagy AAR, Eid HMI, El-Atta MA, and El-Fattah LSA (2009). Isolation of Enterococcus faecalis from Tilapia in Lake Temesh in Ismailia Governorate. Journal of Egyptian Veterinary Medical Association, IVX (2): 45-53. Available at: http://vet.scuegypt.edu.eg/attach/mg3.pdf

MacFaddin JF (2000). Biochemical tests for identification medical bacteria. Warery press, Incorporation. Baltimore, Medicine. 21202 USA.

Martins ML, Tavares-dias M, Fujimoto RY, Onaka EM, and Nomura DT (2004). Haematological alterations of Leporinus macrocephalus (Osteichthyes: Anostomidae) naturally infected by Goezia leporini (Nematoda: Anisakidae) in fish pond. Aquatic Brazilian Medicine Veterinary Zoology, 56(5): 640-646. DOI: http://dx.doi.org/10.1590/S0102-09352004000500011

Mata AI, Blanco MM, Domínguez L, Fernández Garayzábal JF, and Gibello A (2004). Development of a PCR assay for Streptococcus iniae based on the lactate oxidase (lct $\mathrm{O})$ gene with potential diagnostic value. Veterinary Microbiology. 101: 109-116. DOI: https://doi.org/10.1016/j.vetmic.2004.03.012

Netto LN, Leal CAG, Figueiredo HCP (2011). Streptococcus dysgalactiae as an agent of septicaemia in Nile tilapia, Oreochromis niloticus (L.) Journal of Fish Diseases, 34 (3): 251-254. DOI: https://doi.org/10.1111/j.1365-2761.2010.01220.x

Ohnishi K and JO Y (1981). Studies on streptococcal infection in pond-cultured fishes-I. Fish Pathology, 16(2): 63-67. DOI: https://doi.org/10.3147/jsfp.16.63

Osman KM, Al-Maary KS, Mubarak AS, Dawoud TM, Moussa IM, Ibrahim MD, and Fawzy NM (2017). Characterization and susceptibility of streptococci and enterococci isolated from Nile tilapia (Oreochromis niloticus) showing septicaemia in aquaculture and wild sites in Egypt. BMC veterinary research, 13(1): 357. Available at: https://bmcvetres.biomedcentral.com/articles/10.1186/s12917-017-1289-8

Ouissal CB, Jorge B, Pilar C, and Monia E (2015). Lactic acid bacteria associated with the digestive tract and skin of Sea bream (Sparus aurata) cultured in Tunisia. African Journal of Microbiology Research, 9(31): 1853-1865

Qasem JA, Sameer AZ, Salwa AM, Samee AA, Ahmed AM, and Faisal AS (2008). Molecular investigation of Streptococcus agalactiae isolates from environmental samples and fish specimens during a massive fish kill in Kuwait Bay. Pakistan Journal of Biological Sciences, 11(21): 2500. DOI: https://doi.org/10.3923/pjbs.2008.2500.2504

Plumb JA (1997). Infectious disease of tilapia. In B.A. Costa-Pierce, and J.E. Rakocy (Eds.), Tilapia aquaculture in the Americas, Baton Rouge, Louisiana: World Aquaculture Society, 1: 212-228.

Pillay TVR (1992). Aquaculture and the environment, edited by Pillay TVR, first edition, p. 189

Popma T, and Masser M (1999). Tilapia life story and biology. Southern Regional Aquaculture Center Publication No. 283.

Qiang J, He J, Yang H, Xu P, Habte-Tsion HM, Ma XY, and Zhu ZX (2016). The changes in cortisol and expression of immune genes of GIFT tilapia Oreochromis niloticus (L.) at different rearing densities under Streptococcus iniae infection. Aquaculture international, 24(5): $1365-1378$. Available at: https://link.springer.com/article/10.1007/s10499-016-9995-y

Řehulka J (2002). Aeromonas causes severe skin lesions in rainbow trout (Oncorhynchus mykiss): clinical pathology, haematology, and biochemistry. Acta Veterinaria Brno, 71(3): 351-360. Available at: https://actavet.vfu.cz/media/pdf/avb_2002071030351.pdf

Saleh H, Gabr Ali NM, Aboyadak I, and Saber N (2019). Subcellular degenerative changes in hepatopancreas and posterior kidney of Streptococcus iniae infected Nile tilapia using Transmission Electron Microscope. Egyptian Journal of Aquatic Biology and Fisheries, 23(1): 305-316. Available at: https://ejabf.journals.ekb.eg/article_28099_215030df716a9e39cf6bb9e2ac2a350e.pdf 
Sammut J (2001). Associations between acid sulphate soils, estuarine acidification, and gill and skin lesions in estuarine and freshwater fish. PhD dissertation, University of New South Wales, Australia .Available at: https://www.elibrary.ru/item.asp?id=5276900

Swann LD (1992). A basic overview of aquaculture. Technical Bulletin Series No.102. Aquaculture Extension Specialist Illinois-Indiana Sea Grant Program, West Lafaette: Purdue University. A

Tohru F, and Masuko U (2011). Superoxide Dismutases: Role in Redox Signaling, Vascular Function, and Diseases. Antioxidants and Redox Signaling, 15: 1583-1606. DOI: https://doi.org/10.1089/ars.2011.3999.

Wedemeyer GA (1997). Effects of rearing conditions on the health and physiological quality of fish in intensive culture. Fish stress and health in aquaculture, 35-71. Available at: https://ci.nii.ac.jp/naid/10010667900/

Yang JL, and Chen HC (2003). Effects of gallium on common carp (Cyprinuscarpio): acute test, serum biochemistry, and erythrocyte morphology. Chemosphere, 53(8): 877-882. DOI: https://doi.org/10.1016/S0045-6535 (03)00657-X

Yu JH, Han JJ, and Park SW (2010). Haematological and biochemical alterations in Korean catfish Silurus asotus, experimentally infected with Edwardsiella tarda. Aquaculture Research, 41(2): 295-302. DOI: https://doi.org/10.1111/j.1365-2109.2009.02331.x

Zamri-Saad M, Amal MNA, Siti-Zahrah A, and Zulkafli AR (2014). Control and prevention of streptococcosis in cultured tilapia in Malaysia: a review. Pertanika Journal of Tropical Agricultural Science, 37 (4): 389-410. Available at: http://agris.upm.edu.my:8080/dspace/handle/0/9853

Zeid DMM (2004). Studies on streptococcosis among cultured and wild Oreochromis niloticus. M. V. Sc. Thesis Faculty of Veterinary Medicine Suez Canal University.

Zhang XY, Fan HP, Zhou QF, Zhuo YC, Lin Y, and Zeng ZZ (2008). Isolation, identification and pathogenicity of Streptococcus agalactiae from tilapia. Journal of Fisheries of China, 32: 772-779. Available at: http://en.cnki.com.cn/Article en/CJFDTotal-SCKX200805015.htm

Zhao JH, Lam TT and Guo JY (1997). Acute toxicity of ammonia to the early stage-larvae, and juveniles of Eriocheir sinensis H.MilneEdwards, 1853 (Decapoda: Gaspidae) reared in the laboratory, 28: 517-525. DOI: https://doi.org/10.1046/j.1365-2109.1997.00888.x

Zoletti GO, Siqueira JF and Santos KRN (2006). Identification of Enterococcus faecalis in Root-filled Teeth With or Without Peri radicular Lesions by Culture dependent and Independent Approaches. Journal of Endodontics, 32 (8): 722-726. DOI: https://doi.org/10.1016/j.joen.2006.02.001

Zotti FD, Visonà E, Massignani D, Abaterusso C, Lupo A, and Gambaro G (2008). General practitioners serum creatinine recording styles. Journal of nephrology, 21(1): 106-109. Available at: https://www.researchgate.net/publication/5587062 